\title{
Commentary: A chance to cut is a chance to ... prevent metastases?
}

\author{
Jonathan C. Yeung, MD, PhD, FRCSC
}

Surgeons continue to play a vital role in the treatment of lung cancer in the 21 st century, but the operation itself has become mostly routine. The prospect that an aspect of surgical technique could influence metastasis in the future is exciting and represents a rare translational link between surgical care and cancer cell biology. In this issue of the Journal, Wakeam and colleagues ${ }^{1}$ discuss a recent article by Wei and colleagues ${ }^{2}$ on how a "vein-first" surgical technique can potentially reduce the release of circulating tumor cells (CTCs) into the bloodstream during resection and also review the biology of circulating tumor cells.

The concept of CTCs is not a new one. Paget ${ }^{3}$ described $^{-}$ the "seed and soil" theory of cancer metastases almost 150 years previously. However, these "seeds" of cancer metastases have only recently been reliably detected using novel technologies and strategies. ${ }^{4}$ These remain imperfect, with challenges in the sensitivity and reproducibility of CTC detection limiting clinical translation. The other challenge is biological; there is no gold-standard marker that defines a CTC, and CTCs from different cancers will likely be different from each other. ${ }^{5}$ CTC detection is therefore like looking for a needle in a haystack without fully knowing what the needle looks like.

To detect lung cancer CTCs, Wei and colleagues defined a CTC as a circulating cell that carried a folate receptor. They then used an oligonucleotide conjugated to folic acid as a ligand for the receptor and polymerase

From the Division of Thoracic Surgery, Department of Surgery, University of Toronto, Toronto, Ontario, Canada.

Disclosures: The author reported no conflicts of interest.

The Journal policy requires editors and reviewers to disclose conflicts of interest and to decline handling or reviewing manuscripts for which they may have a conflict of interest. The editors and reviewers of this article have no conflicts of interest.

Received for publication July 6, 2020; revisions received July 6, 2020; accepted for publication July 7, 2020; available ahead of print July 12, 2020.

Address for reprints: Jonathan C. Yeung, MD, PhD, FRCSC, Toronto General Hospital, 200 Elizabeth St, 9N-983, Toronto, Ontario, M5G 2C4, Canada (E-mail: jonathan.yeung@uhn.ca).

JTCVS Techniques 2020;3:356-7

2666-2507

Copyright (c) 2020 The Authors. Published by Elsevier Inc. on behalf of The American Association for Thoracic Surgery. This is an open access article under the CC BY-NCND license (http://creativecommons.org/licenses/by-nc-nd/4.0/).

https://doi.org/10.1016/j.xjtc.2020.07.007

chain reaction was used to amplify the oligonucleotide sequence as an indirect measure of folate receptorcontaining cells. ${ }^{6}$ This represents a compromise in balancing sensitivity of detection, CTC biology, and reproducibility. However, it results in data in which CTCs are not directly detected and only cells that possess folate receptors would be classified as CTCs. Wakeam and colleagues highlight the weaknesses in this detection strategy in their article.

The other major issue is whether CTCs thought to be liberated by surgical manipulation of the tumor have any real metastatic potential. Only a very select few CTCs possess metastatic potential, and these cells may need to undergo a transformation such as epithelial-tomesenchymal transformation or another as yet-unknown mechanism before they become metastatic. ${ }^{7}$ Tumor cells released into the bloodstream by a surgeon's grasp may not have these changes and simply die. Moreover, if this transformation results in the loss of the folate receptor, this more dangerous population would not have been identified by Wei and colleagues. Again, Wakeam and colleagues discuss this issue and the difficulties with the early clinical end points established in the study by Wei and colleagues.

As surgeons, we have the privilege of directly impacting patient outcomes in the operating room. A change in technique that could impact metastatic potential in the future, 
especially one as straightforward as a vein-first approach, is extremely enticing. However, there remain technical and biological hurdles in confirming the hypothesis of Wei and colleagues. Future studies are warranted.

\section{References}

1. Wakeam E, Ball H, Reddy R. What's in a vein? J Thorac Cardiovasc Surg Tech. 2020;3:350-3.

2. Wei S, Guo C, He J, Tan Q, Mei J, Yang Z, et al. Effect of vein-first vs artery-first surgical technique on circulating tumor cells and survival in patients with non-small cell lung cancer: a randomized clinical trial and registry-based propensity score matching analysis. JAMA Surg. 2019;154:e190972.
3. Paget S. The distribution of secondary growths in cancer of the breast. 1889 Cancer Metastasis Rev. 1989;8:98-101.

4. Banko P, Lee SY, Nagygyorgy V, Zrínyi M, Chae CH, Cho DH, et al. Technologies for circulating tumor cell separation from whole blood. J Hematol Oncol. 2019; $12: 48$

5. Barriere G, Fici P, Gallerani G, Fabbri F, Zoli W, Rigaud M. Circulating tumor cells and epithelial, mesenchymal and stemness markers: characterization of cell subpopulations. Ann Transl Med. 2014;2:109.

6. Chen X, Zhou F, Li X, Yang G, Zhang L, Ren S, et al. Folate receptor-positive circulating tumor cell detected by LT-PCR-based method as a diagnostic biomarker for non-small-cell lung cancer. J Thorac Oncol. 2015;10:1163-71.

7. Lamouille S, Xu J, Derynck R. Molecular mechanisms of epithelial-mesenchyma transition. Nat Rev Mol Cell Biol. 2014;15:178-96. 